\title{
¿Hacia un nuevo cristianismo? \\ Religión y heterodoxia en la Joven Generación Argentina
}

\author{
por \\ Diego Castelfranco ${ }^{1}$ \\ Instituto de Investigaciones, Pontificia Universidad Católica Argentina / \\ Universidad de San Andrés / CONICET
}

El presente artículo analiza las concepciones religiosas de quienes integraron la Joven Generación Argentina a fines de la década de 1830. Dichos personajes pensaron a la religión, y más específicamente al cristianismo, como un vector de regeneración estrictamente terrenal sobre el cual debía apoyarse - junto a la filosofia - su proyecto de reforma social y política. Manifestaron también una velada hostilidad al catolicismo, asociado a las costumbres coloniales que se pretendía abandonar, a una España que consideraban "retrógrada" y a la "tiranía" de Juan Manuel de Rosas. Sus perspectivas religiosas no constituyeron un planteo sistemático, sin embargo, sino que es pertinente referir a ellas como dando forma a una "estructura de sentimientos".

Palabras ClaVe: Joven Generación Argentina; siglo XIX; cristianismo; Juan Bautista Alberdi; Esteban Echeverría.

Cómo CITAR este artículo / Citation: Castelfranco, Diego, “¿Hacia un nuevo cristianismo? Religión y heterodoxia en la Joven Generación Argentina", Revista de Indias, LXXX/279 (Madrid, 2020): 381-414. https://doi.org/10.3989/revindias.2020.011.

La historiografía abocada al estudio de la Joven Generación Argentina es muy extensa y presenta diferentes inflexiones metodológicas, conceptuales e interpretativas que atravesaron sensibles transformaciones a lo largo del tiempo: la biografía, la historia de las ideas, los estudios sobre sus redes de sociabilidad, el cotejo entre su producción escrita y la de sus referentes intelectuales, las herramientas de la Nueva Historia Intelectual, todas estas vías fueron

1 dcastelfranco@gmail.com, ORCID iD: https://orcid.org/0000-0003-0313-1404 de uso y distribución Creative Commons Reconocimiento 4.0 Internacional (CC BY 4.0). 
recorridas para comprender la trayectoria de un conjunto de personajes cuya central gravitación en la historia argentina del siglo XIX no es sin embargo puesta en duda. A diferencia de lo ocurrido con la Generación del 80, cuya homogeneidad interna es hoy fuertemente cuestionada ${ }^{2}$, el grupo conformado por los jóvenes románticos continúa siendo leído bajo un prisma generacional: compartieron espacios de formación, desarrollaron, al menos inicialmente, un proyecto político y sociocultural compartido, apelaron a los mismos autores franceses para desarrollar sus ideas y coincidieron en un acotado conjunto de ámbitos de sociabilidad intelectual.

A pesar de ello, un elemento resultó por lo general soslayado en dicho corpus de estudios: sus apreciaciones sobre la religión. Con algunas excepciones $^{3}$, la bibliografía sobre el tema tendió a obviar la recepción y reelaboración de los discursos religiosos que circulaban en Europa, otorgando un papel muy menor a las referencias de este tipo que, sin embargo, una y otra vez emergieron en sus textos. Asimismo, no se prestó particular atención al modo en que la reflexión sobre dichas cuestiones tuvo un papel destacado en la elaboración de un novedoso lenguaje político por parte de los jóvenes románticos.

Este artículo analiza el pensamiento de algunos integrantes de la Generación de 1837 en lo relativo a sus ideas sobre la religión. Se vale, para ello, de dos herramientas conceptuales: la noción de "lenguajes políticos", según la formulara J. G. A. Pocock, y la de "estructura de sentimiento", siguiendo la propuesta de Raymond Williams. El texto se construye sobre la base de dos postulados. En primer lugar, que los miembros de la Nueva Generación intervinieron sobre la incipiente esfera pública porteña apelando a un novedoso lenguaje político, estructurado, mayormente, en torno a un cierto historicismo matizado, de cuño francés. En segundo lugar, que en el marco de dicha perspectiva historicista articularon novedosas concepciones en torno a

2 Bruno, 2007.

3 José Ingenieros, hace ya más de un siglo, caracterizó el pensamiento de la Joven Generación como marcado por un fuerte anticatolicismo que se sustentaba sobre un marco de referencias sansimoniano. Jorge Myers, más contemporáneamente, enfatizó la impronta laica de su formación intelectual y el modo en que el reencuentro con el catolicismo de algunos de sus integrantes debe ser pensado como una "vuelta al seno". Roberto Di Stefano fue quizá quien dedicara una mayor atención a esta temática. A su modo de ver, una genérica adhesión a la fe cristiana convivía con críticas más o menos veladas a las prácticas del catolicismo heredado. Más allá de la riqueza de algunas de estas perspectivas, ninguno de los autores mencionados centró su atención en esta temática específica o analizó la imbricación de sus concepciones religiosas y su lenguaje político. Ingenieros, 1961, vol. 2: 235-310 y Di Stefano, 2010: 180-181. 
la religión, que se apartaron de las discusiones a ese respecto que se habían desarrollado en Buenos Aires a partir de 1810. Personajes como Juan Bautista Alberdi, Manuel Quiroga Rosas, Esteban Echeverría y Félix Frías, con una mirada tácitamente adversa hacia el catolicismo, articularon un discurso con un fuerte carácter "heterodoxo". Este discurso, sin embargo, no conformó una totalidad sistemática, sino que se nutrió de ciertas nociones vagamente compartidas y se constituyó con igual fuerza en torno a lo efectivamente expresado como a los hiatos presentes en su enunciación. Considero pertinente, en ese sentido, referir a una cierta "estructura de sentimiento" que atravesó a los miembros de la Nueva Generación y que solo se resolvería, por medio de su materialización en proyectos intelectuales divergentes, muchos años más adelante.

\section{Nueva GeNERACión, NUEVOS LENGUAJES POLÍTicos}

En 1821, bajo el influjo de Bernardino Rivadavia, el gobernador bonaerense Martín Rodríguez decretó la fundación de la Universidad de Buenos Aires. En 1823, también por iniciativa de Rivadavia, se creaba el Colegio de Ciencias Morales como sucesor del Colegio de la Unión del Sud. Estos espacios de formación académica resultarían centrales en el proyecto rivadaviano de "expansión de las luces", y encarnaron un paso decisivo en la laicización de la enseñanza en Buenos Aires. Las cátedras de filosofía, tradicionalmente en manos de eclesiásticos, quedarían en los años subsiguientes en manos de profesores en su mayoría laicos: Juan Crisóstomo Lafinur, Juan Manuel Fernández de Agüero - que, a pesar de ser sacerdote, era el más radicalmente anticlerical de todos ellos ${ }^{4}$-, Diego Alcorta y Luis José de la Peña. Sus doctrinas fueron las los philosophes dieciochescos - Condillac, en particular - y las de sus herederos intelectuales, los idéologues — Destutt de Tracy, Cabanis y Laromiguière, entre otros -5 . En las aulas que regenteaban se

${ }^{4}$ Fernández de Agüero propugnaría una religión y una moral naturales, que se correspondían, a su entender, con el verdadero mensaje de un Jesucristo más filósofo que mesías. Según Roberto Di Stefano, «La propuesta de Fernández de Agüero [...] apuntaba a reacomodar el lugar de lo sagrado en la vida colectiva proclamando las bases naturales de la moral y predicando el culto del Dios invisible». Acusado de impiedad, el profesor heterodoxo sería finalmente desplazado al mismo tiempo que la presidencia de Rivadavia se derrumbaba. Ver Di Stefano, 2010: 161-166.

5 Condillac era uno de los autores cuyo pensamiento actuaba como base para el curso de filosofía de Diego Alcorta, uno de los profesores más cercanos a la "joven generación". Alcorta, 2001. Sobre la recepción de Cabanis y De Tracy puede consultarse Di Pasquale, 2011 y 2013. 
formarían y entablarían amistad la mayor parte de quienes integraron la Joven Generación Argentina: Juan Bautista Alberdi, Juan Manuel Gutiérrez, Félix Frías, Vicente Fidel López, Manuel José Quiroga Rosas y Miguel Cané (padre), por nombrar solo a algunos de ellos.

Al sustentar su legitimidad en los saberes recibidos a través de su formación, la Joven Generación dio un paso fundamental en la conformación de la figura del "intelectual" moderno ${ }^{6}$. En palabras de Jorge Myers:

El hecho de recibir su educación en un establecimiento del Estado, que por su organización tanto como por su ideología rectora estaba netamente deslindado de cualquier relación orgánica con la religión oficial, hizo de esta generación intelectual la primera que pudo concebir su lugar en la sociedad y en la cultura en términos "modernos", en vez de hacerlo en los términos heredados del Antiguo Régimen. En la Argentina la instancia fundamental, la ruptura conceptual que instaura la figura social del "intelectual", se sitúa en el momento de emergencia de la Nueva Generación romántica. Este sería concebido en términos de su autonomía frente a los poderes constituidos de una sociedad como el Estado, la Iglesia, las corporaciones y clases tradicionales, en reemplazo del 'letrado' colonial o del 'clero' de la tradición medieval, cuyo papel social estaba determinado por la exigencia constitutiva de servir al orden político establecido y de defender y propagar las 'verdades reveladas' de la fe ${ }^{7}$.

Si durante el período colonial los letrados se habían abocado a la defensa del orden y de sus prerrogativas corporativas, y en las dos primeras décadas postrevolucionarias los nuevos publicistas habían sido capturados, en muchos casos, dentro de un entramado de ineludibles lazos políticos, esto comenzaría a cambiar en la década de $1830^{8}$. Y no solo por los nuevos saberes que los jóvenes estudiantes incorporaron, sino también por la apertura de novedosos espacios de circulación e intercambio cultural. Como refiere Pilar González Bernaldo, las instituciones de enseñanza creadas por Rivadavia darían vida a una "sociabilidad estudiantil" que le estuvo íntimamente asociada9. Según esta autora, la universidad prolongó y completó la esfera pública literaria —en

6 Más allá de que el uso término "intelectual” para referir a la experiencia temprana de los jóvenes románticos pueda presentar algunas aristas problemáticas, dada su amplia polisemia. Sobre este punto ver Diego Castelfranco, 2018: 59-67.

7 Myers, 1998: 389.

8 Sobre este tema puede consultarse Myers, 2008, vol. 1: 29-52; Halperin Donghi, 1987: 41-64 y Lempérière, 2008.

9 Una de sus primeras manifestaciones fue la Asociación de estudios históricos y sociales, fundada en 1832 por, entre otros, Félix Frías y Miguel Cané. Los novedosos "gabinetes de lectura" establecidos por algunas librerías porteñas, y sobre todo por la de Marcos Sastre, se convertirían también en núcleos centrales de esta sociabilidad estudiantil. Sus exponentes más relevantes, sin embargo, fueron el Salón Literario fundado en 1837, que de hecho absorbió a 
proceso de expansión durante la primera mitad de la década de 1830_- a partir de la cual surgiría - aunque mayormente en el exilio - una esfera pública política. La sociabilidad estudiantil, así, alcanzaría un fuerte ascendiente en el mundo de los intercambios culturales urbanos, apuntando a estimular una "sociabilidad culta" en la que la "Sociedad" se convertía en un tema de interés público ${ }^{10}$.

Los encuentros en las aulas rivadavianas resultaron fundamentales para la formación de esta nueva camada intelectual, tanto por sus intercambios con los profesores ${ }^{11}$ como por aquellos realizados por los propios alumnos entre sí $^{12}$. Estos últimos, de hecho, se extendieron crecientemente puertas afuera del colegio y la universidad, conjugándose con las nuevas oportunidades culturales ofrecidas por una Buenos Aires cuyos espacios de sociabilidad intelectual se encontraban en expansión. Como indica Félix Weinberg, el número de librerías en la ciudad pasó de cinco en 1830 al doble en $1836^{13}$. Y no solo se multiplicaron en número, sino que también expandieron los servicios que ofrecían a sus potenciales clientes. Incorporaron durante esos años un sistema de préstamos domiciliarios y, más importante aún, constituyeron "gabinetes de lectura" que permitían a los concurrentes, a cambio de una suma módica de dinero, acceder a las últimas novedades en materia de revistas y libros extranjeros. Los jóvenes letrados podían así consultar un conjunto de obras y publicaciones periódicas - Revue de Paris, Revue Britannique, Revue Encyclopédique, Revue des Deux Mondes, entre otras- que exponían las más "avanzadas" doctrinas europeas y francesas en particular.

La importancia de los gabinetes de lectura no residía solamente en permitir a lectores sin demasiados recursos, como lo eran muchos estudiantes, el acceso estos nuevos corpus textuales. Conformaron también espacios de encuentro y devinieron en nodos centrales de la sociabilidad estudiantil. Allí no

un público más amplio que el de los estudiantes, y la Asociación de la Joven Argentina, de 1838, que se encontró mucho más abocada a la acción política.

10 González Bernaldo, 2008: 117.

11 Como afirma Vicente Fidel López en su "Autobiografía”, tanto él como la mayor parte de sus compañeros desarrollarían un vínculo particularmente estrecho con su profesor de filosofía, Diego Alcorta. En palabras de López, Alcorta «era un amigo y compañero para nosotros; comíamos y almorzábamos en su casa y vivíamos alrededor de su persona y de su familia: hablábamos con él de todo; no tuvo hijos, y nosotros éramos para él la corona doméstica y universitaria». López, 1896: 333.

12 Muchos años más tarde, al escribir su breve autobiografía, Alberdi recordaría cómo su amistad con Miguel Cané lo había alejado de la aburrida lección que el profesor Mariano Guerra dictaba sobre Virgilio, permitiéndole introducirse en el apasionante universo de las obras rousseaunianas. Alberdi, 1953: 40.

13 Weinberg, 1977: 18. 
solo se leía; los conceptos adquiridos podían también ponerse en común y discutirse. Marcos Sastre, dueño de la librería más frecuentada por los alumnos de la universidad, finalmente intentaría institucionalizar este tipo de reuniones informales con la ayuda de Gutiérrez y de Alberdi. Sastre pretendía formar en su librería una especie de club de discusión, conversación y lectura $^{14}$. Esto daría vida en junio de 1837 a la creación del Salón Literario, espacio de fundamental importancia, aunque escasa duración, donde los jóvenes románticos pudieron elaborar y difundir sus perspectivas sobre la realidad nacional y su proyectada transformación.

Un problema central al que los miembros de la Joven Generación intentaron otorgar una respuesta, en efecto, fue el de la nacionalidad. El dilema era relativamente claro: ¿cómo fundar la nacionalidad sobre un conjunto de características que pudieran ser consideradas propias, cuando esas características representaban el atraso del orden colonial-español, devenido, de algún modo, lo antinacional por excelencia? O, invirtiendo los términos de la pregunta, ¿cómo apelar a un orden externo de ideas y costumbres "civilizadas" para fundar la nación, sin vaciar de todo contenido propio a esa nación que se pretendía fundar? La respuesta a esta disyuntiva, quizá irresoluble, residiría en un equilibrio siempre inestable, cambiante de acuerdo a las circunstancias, entre ese componente "universal" que se creía encontrar en Europa y las costumbres y formas propias ${ }^{15}$.

Al enfatizar el elemento nacional como eje central de cualquier proyecto de reforma, los jóvenes románticos explicitaban su ruptura con lo que habían aprendido en las aulas rivadavianas y con aquellas ideas y autores que, a su modo de ver, constituían el núcleo del pensamiento que había guiado a la generación precedente. Denunciando la esterilidad de autores como Condillac y Destutt de Tracy, que habían leído en sus años formativos, y de una línea benthamiana que consideraban axial en el discurso de los rivadavianos, los integrantes de la Nueva Generación abrevaron de un nuevo corpus teórico que los conduciría a construir sus discursos sobre la base de un novedoso lenguaje político ${ }^{16}$.

14 Ibidem, 44.

15 Según Elías Palti, «La visión histórica de la Generación del 37, a pesar de su retórica historicista, difícilmente (y solo tardíamente) habrá de superar las limitaciones que surgían de aquel rechazo al pasado colonial en bloc. Permanecerá desgarrada entre, por un lado, su vocación (que compartía con la generación revolucionaria que la precedió) por erradicar los principios sociales tradicionalistas heredados de la colonia y, por otro, su crítica a la idea iluminista de que un pueblo puede modificar su naturaleza y costumbres a voluntad (idea que, pensaban, no podía sino llevar a la anarquía». Palti, 2009: 27.

16 De acuerdo con Pocock, los lenguajes políticos pueden ser definidos como «una forma de hablar y escribir que es reconocible, internamente consistente, capaz de ser 'aprendido', y 
En aras de materializar las promesas de la Revolución, consideraban, era preciso encontrar esa "civilización propia", americana, rompiendo los moldes universalistas centrados en el sensualismo de los philosophes o en la utilidad benthamiana. El historicismo romántico, llegado a Alberdi por medio de Lerminier y de su peculiar reelaboración de las nociones jurídico-filosóficas de Savigny, ocuparía así el centro de la escena. Según Elías Palti,

Lo que el concepto historicista romántico sostenía no era ciertamente la obviedad de que haya que adecuar los sistemas institucionales a las culturas y tradiciones locales dadas sino, más precisamente, que no se podría pretender imponérseles un determinado curso evolutivo si este no formara ya parte de ellas como una de sus alternativas potenciales de desarrollo. La acción política solo podría, pues, alentar o desalentar aquellas tendencias evolutivas inherentes suyas, pero no crearlas ex nihilo ${ }^{17}$.

Los jóvenes románticos contemplaban en el pensamiento rivadaviano, y particularmente en el pensamiento de Bentham, la entronización de un sujeto individual deshistorizado cuya acción podía reducirse a ciertos criterios fundamentales - regidos por el principio de utilidad - y así universalizarse. Esto solo podía dar lugar, a su entender, a la formación de instituciones "artificiales" que no se condecían con las características propias del territorio rioplatense - siendo el sufragio universal la más clara de entre ellas-.

\section{¿HACIA Un NUEVO CRISTIANISMO?}

En un plano muy diferente, las principales discusiones religiosas de la década de 1830 continuaron girando, de forma similar a las décadas anteriores, en torno al patronato y al tipo de relación que deberían sostener el Estado y la Iglesia. Las posiciones en disputa, como señala Roberto Di Stefano, pueden reducirse a una perspectiva galicana y una perspectiva "intransigente"; esto es, la opción entre una Iglesia a imagen y semejanza —o, más aún, al servicio de - el Estado, frente a la visión que veía en Roma a la cabeza de

suficientemente distinto de otros como como él para permitirnos considerar qué ocurre cuando una expresión o problema migra, o es traducido, fuera de ese contexto hacia otro». Propugna a partir de ello un modelo heurístico «en el que un número de paradigmas lingüísticos [...] pueden ser reconocidos como ocurriendo al mismo tiempo, pudiendo ser distinguidos y que interactúan entre ellos, de modo que un debate puede ser visto como desarrollado en un texto complejo escrito en numerosos idiomas y en varios niveles de sentido de forma simultánea». Pocock, 2009: 77-78.

17 Palti 2009: 34. 
esa "sociedad perfecta" que era la Iglesia católica y sobre la cual el Estado no tenía ningún derecho a intervenir - cuando menos sin su consentimiento- ${ }^{18}$. La fe católica, a su vez, entraría de lleno en un cierto discurso de orden, sustentado en un lenguaje republicano, por medio del cual los publicistas rosistas pretendieron legitimar al régimen. Como señala Jorge Myers, Rosas identificó a su gobierno con la causa de la ortodoxia católica y una parte importante de su discurso se enfocaría en destacar la impiedad de sus opositores y en remarcar su voluntad de restaurar la religión nacional ${ }^{19}$.

Las perspectivas galicana e intransigente compartían, sin embargo, un fundamento que las acercaba: incluso en sus enunciaciones menos enfáticas, ninguna de ellas esbozaba siquiera una ruptura con la idea de que la sociedad era católica, y que por la tanto esa fe debía ser adoptada oficialmente por el Estado $^{20}$. Los jóvenes de la Nueva Generación, en cambio, comenzaron a expresar opiniones que manifestaban una clara disonancia con ese statu quo religioso. No se trataba ya de subordinar la Iglesia al Estado y convertirla en una parte funcional de este, como habían anhelado los rivadavianos, ni de situarla bajo el poder de un papado que era contemplado como la cabeza de una Iglesia universal. El cristianismo sería ahora entronizado como un motor y elemento constitutivo progreso humano, que llevaba la simiente de un orden igualitario y democrático. La religión, aliada a la filosofía, permitiría avanzar hacia una fe nueva en la que todos los hombres —o todas las naciones, y todos los hombres en cuanto integrantes de ellas - comulgarían, y que abriría una etapa de regeneración moral y social. En esta fe común de la humanidad, según la perspectiva de los jóvenes románticos, el papel de la Iglesia católica podía convertirse más en un escollo que en un apoyo efectivo.

Los miembros de la Generación del 37 no encontraron su modelo de religión ni en el catolicismo tradicional ni en el deísmo de los philosphes, sino en las variantes del espiritualismo que se expandió ampliamente en la Francia

18 Di Stefano, 2004: 155-192.

19 Myers, 1995: 286-288.

20 Algunas voces aisladas habían puesto en duda el carácter esencialmente católico de las Provincias Unidas en la década anterior, a partir de una postura que podría ser leída como liberal: pueden contarse entre ellas las de Julián Segundo de Agüero, Juan José Paso y José Francisco Ugarteche. Durante las décadas de 1830 y 1840 el espacio para opiniones de este tipo parece haber sido, en el ámbito gubernativo al menos, más acotado. En el Memorial Ajustado, que según Ignacio Martínez es «una de las piezas documentales donde se trata con mayor exhaustividad y complejidad el dilema del gobierno de las iglesias argentinas para el período 1820-1852», dichas nociones no emergieron. Para un análisis del Memorial Ajustado puede consultarse Martínez, 2013: 289-313. Sobre las posturas "liberales" con respecto al vínculo entre la Iglesia y el Estado ver Di Stefano, 2004: 172-177. 
de la Restauración y de la monarquía de julio. Paul Bénichou resalta la omnipresencia del tema religioso en las doctrinas políticas y sociales a lo largo de dicho período. Un elemento compartido por filósofos y pensadores tan disímiles como Jouffroy, Lamennais, Leroux y Quinet era la necesidad de dar forma a una "creencia pública" que permitiera reconstituir los lazos de una sociedad que la filosofía del siglo XVIII, según la opinión dominante en la época, había tendido a disolver a través de la generalización de la crítica y el libre examen. El nuevo dogma unificador que se perseguía se situaba en una zona ambivalente entre la confianza en una providencia trascendente, que ataba el destino de la humanidad a la ley general del progreso, y una suerte de religión humanitaria, que apuntaba, en cierta forma, a la apoteosis del colectivo humano ${ }^{21}$.

Las nuevas lecturas, sobre todo francesas, a que accedieron los jóvenes románticos durante la década de 1830 tuvieron una fuerte influencia sobre su modo de contemplar dichas cuestiones ${ }^{22}$. Como señalara Vicente Fidel López, en un pasaje numerosas veces citado de su autobiografía:

Á los influjos de mis cursos con Alcorta, se agregan los de un grande acontecimiento que trastornó las bases sociales del mundo europeo - la revolución de 1830 - que sacó a los Borbones del trono de Francia, y puso en él a Luis Felipe de Orleans. Nadie hoy es capaz de hacerse una idea del sacudimiento moral que este suceso produjo en la juventud argentina que cursaba en las aulas universitarias. No sé cómo produjo una entrada torrencial de libros y autores que no se había oído mencionar hasta entonces. Las obras de Cousin, de Villemain, de Quinet, Michelet, Jules Janin, Merimée, Nisard, etc., andaban en nuestras manos produciendo una novelería fantástica de ideas y de prédica sobre escuelas y autores - románticos, clásicos, eclécticos, San Simonianos-. Nos arrebatábamos las obras de Victor Hugo, de Sainte-Beuve, las tragedias de Casimir Delavigne, los dramas de Dumas y de Victor Ducange, Georges Sand, etc. Fué entonces que pudimos estudiar á

21 Bénichou, 2012.

22 Esto no solo ocurrió en el plano de la recepción de las ideas francesas, sino en el de los modelos imaginados para la actuación pública de esta nueva generación de publicistas. Como lo indica María Mercedes Betria Nassif: «Más que sus ideas, lo que había tenido un valor performativo importante para la Generación del 37 había sido el propio Jouffroy quien, en tanto escritor y profesor, había legitimado públicamente en la prensa la aspiración de los nuevos publicistas al manifestar que todas las generaciones tenían una tarea específica en el movimiento de la historia y en la renovación de los dogmas y que había llegado la hora de la nueva generación, destinada a ser la autora de una nueva moral filosófica laica para conducir la revolución de las ideas». Si bien los jóvenes románticos porteños no tomaron de Jouffroy su idea inicial de reemplazar al cristianismo por una nueva creencia colectiva de carácter filosófico, es difícil dudar que dicho personaje actuó para ellos como un referente a la hora de pensarse - en palabras de Betria Nassif - como los creadores de un nuevo "movimiento intelectual". Betria Nassif, 2013: 3 y 145 
Niebhur y que nuestro espíritu tomó alas hacia lo que creíamos las alturas. La Revue de París, donde todo lo nuevo y trascendental de la literatura francesa de 1830 ensayó sus fuerzas, era buscado como lo más palpitante de nuestros deseos ${ }^{23}$.

Dentro de ese torrente de obras franceses llegaron a manos de quienes integraron la Joven Generación un conjunto de volúmenes que les permitirían repensar ciertos elementos relativos al papel de la religión, en general, y del cristianismo en particular. La "Librería Argentina" de Marcos Sastre, íntimamente asociada al nacimiento del Salón Literario, constituyó una de las fuentes privilegiadas de acceso a dicho caudal de nuevos trabajos. Al disolverse tanto la librería como el Salón, en 1838, Sastre decidió liquidar sus existencias; entre ellas se contaban, por ejemplo, volúmenes tanto de Lamennais $^{24}$ como de Lerminier ${ }^{25}$. También el Cours de droit naturel y los Mélanges Philosophiques de Jouffroy circularon entre este grupo de jóvenes ávidos de novedades ${ }^{26}$. Con respecto a los escritos de Leroux, los jóvenes románticos pudieron acceder a ellos a través de las revistas que llegaban a las librerías de Buenos Aires y, particularmente, por medio de la Revue Encyclopédique ${ }^{27}$.

\section{López, 1896: 336.}

24 Durante el período circularon en Buenos Aires, al menos, dos obras redactadas por dicho autor: el Ensayo sobre la indiferencia en materia de religión [1817-1823], sobre el cual giró uno de los encuentros del Salón Literario, y las Palabras de un creyente. Esta última obra fue parcialmente traducida por Juan María Gutiérrez para un número de El Recopilador en 1836. Gutiérrez debe haber contado con una edición original del francés, puesto que su traducción es diferente a la realizada por Mariano José de Larra, publicada en Madrid también en 1836. Ver El Recopilador. Museo Americano, tomo 2, cuaderno $2^{\circ}$, agosto, septiembre y octubre de 1836: 12-13 y Lamennais, 1836.

25 Resulta indudable que Alberdi contaba con un volumen de la Introduction générale á l'histoire du droit, como lo afirma en su Fragmento Preliminar. Ver Alberdi, 1886: 103. También consultó las Lettres philosophiques adressées á un Berlinois para exponer, en su Fragmento, las trayectorias de personajes como Royer-Collard, Guizot y Cousin. Alberdi, 1886: 240-244. Es difícil saber, sin embargo, si accedió a ellas por medio de la Revue des Deux Mondes, que las publicó en sucesivas ediciones durante 1832, o a través del libro publicado por Lerminier el año siguiente. Lerminier, 1833.

${ }^{26}$ Félix Frías contaba con una edición del Cours de droit naturel al momento de marchar al exilio, en 1839. Tras partir a Montevideo envió una carta a su hermano Juan donde le solicitaba el envío, entre otras cosas, de los dos tomos comprendidos por dicha obra. Carta de Félix a Juan Frías, 21 de febrero de 1839, en Archivo Félix Frías, Archivo General de la Nación. Vicente Fidel López, por otra parte, elogiaría los Mélanges Philosophiques que había leído en una carta dirigida a Frías. Ver Betria Nassif, 2013.

27 Como sostiene Horacio Tarcus, «las revistas [entre ellas la Revue Encyclopédique] se recibían regularmente a través de una suscripción, que podían administrar los libreros mismos». Tarcus, 2016: 120. 
Ya fuera por medio de las bibliotecas de sus amigos acaudalados - como Santiago Viola, quien había hecho traer de Europa un extenso conjunto de libros y revistas-, de las florecientes librerías porteñas — con sus novedoso sistema de préstamo a domicilio y sus gabinetes de lectura- o por medio del aporte de viajeros o familiares, los integrantes de la Nueva Generación dispusieron de diversas lecturas a partir de cuya lectura - como se verá, siempre selectiva - podrían apartarse de las perspectivas imperantes sobre el rol social de la religión en el Río de la Plata ${ }^{28}$.

\section{LA CONFORMACIÓN DE UNA NOVEDOSA "ESTRUCTURA DE SENTIMIENTO" EN TORNO A LA CUESTIÓN RELIGIOSA}

Pueden encontrarse en las ideas de los jóvenes románticos ciertos puntos comunes, más o menos explícitos, que las dota de un relativo nivel de coherencia. En primer lugar, en todos sus escritos aludieron al cristianismo y a un Dios providencial, pero rarísima vez refirieron al catolicismo y menos aún a la Iglesia, en cuanto institución, y a su clero. En segundo lugar, expresaron que el cristianismo debía aliarse con la filosofía con el objeto de llevar adelante la regeneración de la sociedad, en el marco de su proyecto general de fundar un nuevo orden social estable a partir de una transformación de las ideas y las costumbres locales. En esta ecuación, planteada muchas veces de un modo ambiguo, tendió a ser la filosofía la fuerza destinada a "llevar las riendas" de este gran movimiento palingenésico. En tercer lugar, aunque también ambiguamente, hablaron de una religión que se encontraba estrictamente al servicio de la regeneración social, sin miras escatológicas de ningún tipo. Si bien el concepto de Dios nunca desapareció de sus textos, fue incluido en el marco de una religión que se ajustaba estrictamente a las necesidades de la humanidad y del progreso humanitario —o, quizá, del progreso indefinido, según la formulación de Pierre Leroux - más que en el de una religión escatológica centrada en torno a la revelación divina. Esto es, su religión era más una religión para la humanidad que una religión para algún Dios personal. En cuarto lugar, y vinculado a lo anterior, invocaron al cristianismo mucho más en su dimensión moral que en su dimensión teológica. Si bien esto no era nuevo, dado que en cierta forma las reformas borbónicas y los rivadavianos habían hecho algo similar, para los románticos el cristianismo sería mucho un vector de igualdad y democracia que de ilustración. La promesa encarnada

28 Sobre la circulación de libros y revistas en la Buenos Aires de este período puede consultarse Tarcus, 2016; Buonocuore, 1969 y Weinberg, 1977. 
por el evangelio, a su modo de ver, era la igualación general de todos los hombres. En quinto lugar, esta noción religiosa se confundió muchas veces con la búsqueda de formular un dogma social que se ajustara estrictamente a las condiciones de la población local, aunque sin dejar de contemplar el desarrollo general de la humanidad. En sexto y último lugar, puede argumentarse que, si bien la mayor parte de estas nociones fueron extraídas de autores como Lamennais, Jouffroy y Leroux, las ideas de los románticos argentinos se mostraron mucho más moderadas que las de sus pretendidos mentores intelectuales. Durante esta primera etapa ninguno de ellos rompió públicamente con la fe católica, o llegó a defender la idea de una nueva filosofía -o religión-filosofía - que fuera a suceder al cristianismo.

Es necesario, por otro lado, realizar una aclaración adicional. Si bien los elementos antes mencionados pueden encontrarse en buena parte de los escritos de la Joven Generación, de forma más o menos explícita, no puede sin embargo afirmarse que hayan llegado a sistematizarlas y a otorgarles una forma por completo consistente. Parecen ser atisbos de un pensamiento en formación, más que productos de un pensamiento cuyos límites fueran ya relativamente claros. Es por este motivo que, considero, es pertinente referir a sus ideas religiosas como formando una estructura de sentimiento, de acuerdo con el concepto acuñado por Raymond Williams ${ }^{29}$. Este autor, criticando que muchas veces se presente el movimiento vivo de los sujetos y de las relaciones sociales en las que están insertos como productos acabados, considera que:

justamente porque toda conciencia es social, sus procesos tienen lugar no sólo entre, sino dentro de la relación y de lo relacionado. Y esta conciencia práctica es

29 Si bien el concepto de "estructura de sentimientos" no ha sido utilizado de un modo muy amplio para el estudio de la historio intelectual y cultural del Río de la Plata en el siglo XIX, existen algunos trabajos específicos en que fue tomado como una herramienta analítica. Es el caso, particularmente, de Jorge Myers en «Las paradojas de la opinión. El discurso político rivadaviano y sus dos polos: el 'el gobierno de las Luces' y la opinión pública, reina del mundo» y «La Revolución en las ideas: la generación romántica de 1837 en la cultura y en la política argentinas». Dicha noción aparece allí para explicar ciertos elementos de la recepción realizada por la Nueva Generación del acervo romántico europeo, por un lado, y para referir, por el otro, a una "estructura de sentimiento neoborbónica" propia de los rivadavianos en la década de 1820. Sobre la utilización de dicho concepto en la historiografía argentina abocada al siglo XIX puede consultarse Di Pasquale, 2012: 41-44.

El propio Williams, por otro lado, aplicó extensamente dicha herramienta conceptual al estudio de la cultura inglesa del siglo XIX en The Long Revolution [1961] —aunque también la utilizara para examinar el universo artístico de vanguardia durante el siglo XX, por ejemplo, en Drama from Ibsen to Brecht [1969]—. Williams, así, concede a sus "estructuras de sentimiento" una aplicación temporal relativamente dilatada. 
siempre algo más que una manipulación de formas unidas fijas. Suele haber una tensión entre la interpretación recibida y la experiencia práctica. Donde esta tensión pueda hacerse directa y explícita, nos hallamos todavía dentro de una dimensión de formas relativamente fijas. Sin embargo, la tensión es a menudo una inquietud, una presión, un desplazamiento, una latencia [...] la alternativa real en relación con las formas fijas producidas y recibidas [...] Es un tipo de sentimiento y pensamiento efectivamente social y material, aunque cada uno de ellos en una fase embrionaria antes de convertirse en un intercambio plenamente articulado y definido ${ }^{30}$.

Los integrantes de la Joven Generación, efectivamente, no llegaron a plasmar sus ideas religiosas de forma sistemática, oponiendo una concepción completamente consistente de la esfera religiosa a aquellas que circularon en el Río de la Plata durante la década de 1830 . Como antes se señaló, evitaron una ruptura explícita con el catolicismo, aunque sí expusieron un conjunto de ideas que vaciaban en gran medida de sentido a dicha fe. Sin rechazarla claramente, pero sin tampoco adoptarla, se ubicaron en una suerte de "zona gris" habitada por esas inquietudes, presiones, desplazamientos y latencias descriptas por Williams.

El primer indicio consistente de estas nuevas nociones religiosas puede observarse en las traducciones de las Palabras de un creyente de Lamennais realizadas por Juan María Gutiérrez y publicadas en El recopilador ${ }^{31}$. Para ese año, Gregorio XVI había ya emitido la encíclia Singulari Nos (1834) y Lamennais se encontraba virtualmente fuera de la Iglesia católica. El papa había denunciado que el libro era «pequeño en volumen, enorme en maldad». Eso no impidió que Gutiérrez tradujera y publicara varios capítulos.

Al hacerlo no traspuso ciertos límites, sin embargo. No reprodujo las alusiones de Lamennais a los clérigos devenidos en vástagos del poder, que ayudaban a los reyes a oprimir al pueblo. En la sociedad porteña de ese período, en que regía la censura para cualquier escrito que atacara a la fe católica, esa inclusión hubiera sido posiblemente excesiva ${ }^{32}$. Un elemento clave de la mencionada estructura de sentimiento en la que el cristianismo se confundía con un credo humanitario, sin embargo, ya comenzaba a emerger: la noción de que el cristianismo, y la figura de Jesús ${ }^{33}$, guiarían a los pueblos en una cruzada democrática y de regeneración.

30 Williams, 2009: 172-173.

31 Este periódico, cuya edición se extendió a lo largo de 1836, tuvo a Gutiérrez como redactor principal e incluyó textos de Juan Thompson y Esteban Echeverría. Weinberg, 1977: 26.

32 Sobre la censura ateniente a las publicaciones que trataran sobre el catolicismo puede consultarse Calvo 2004; 2008 y González Bernaldo 2003.

33 Siguiendo el texto reproducido por Gutiérrez: «Por la parte del Septetrion, veo unos hombres á quienes solo les queda un poco de calor concentrado en sus cabezas, calor que les embriaga; pero tócales Cristo con la cruz, y el corazon les late de nuevo. / Al Mediodia veo 
Las referencias al catolicismo se encontraron casi por completo ausentes en los artículos traducidos o redactados por Gutiérrez. Solo emergieron, acotadamente, recubiertas por la forma de un antiespañolismo que era común a la Joven Generación ${ }^{34}$. El periódico editó un artículo de José Joaquín de Mora - más vinculado al grupo rivadaviano que al romántico- titulado Ensayo histórico sobre la poesía española. Desde su orígen hasta Góngora. Allí, mientras indagaba sobre los orígenes de la poesía española, se preguntaba: «¿Cuál es la causa de que ninguna de las naciones católicas haya seguido un sistema de fanatismo y persecución tan decidido, tan general, tan violento, como la española, desde los tiempos de Pelayo hasta nuestros días?» ${ }^{35}$. Su respuesta era que ningún pueblo europeo se había formado y crecido en medio de guerras de religión, ni se habían convertido estas en la base de la instrucción social. De esas causas habían nacido, según Mora, las extravagantes devociones españolas, el ciego respeto hacia los ministros de la religión, cuya causa se aunaba con la de los intereses nacionales, y el establecimiento de la inquisición, considerado como un instrumento de guerra ${ }^{36}$. Estas reflexiones, escritas por Mora a mediados de la década de 1820, entraban solo transversalmente en su ensayo y no atacaban al catolicismo en general, sino solo a un catolicismo español que se consideraba fanático y vinculado al despotismo absolutista ${ }^{37}$.

En 1837, un año después de que Gutiérrez comenzara a redactar El Recopilador, Alberdi publicó su seminal Fragmento preliminar a la historia del derecho. La apropiación y resignificación de las cuestiones religiosas se mos-

ciertas razas agobiadas bajo el peso de no sé que maldición; pero Cristo les toca con la cruz y se enderezan». Rodríguez Martín, 2005: 14.

34 Sobre este tema puede consultarse Falcón, 2005.

35 El Recopilador, no. 6, s/f

36 Idem.

37 En el ámbito privado, no alcanzado por la censura oficial, Gutiérrez sostendría una postura más explícitamente hostil al clero rioplatense. En una carta de 1835 le imprimía una nota humorística a su narración sobre la bendición de las nuevas campanas que había adquirido el templo de San Francisco: «los padres han hecho venir tres campanas nuevas, de los reinos de Italia, país fecundísimo en esta especie de artefactos místicos; su Ilustrísima ex aulonense [Medrano] con las ceremonias que acertadamente prescribe para tales casos el ritual romano: era de ver al obispo con los ojos vendados, ir y venir de una a otra campana, echarles comunidad con casullas y estolas y mucha formalidad. Los sordos han mirado con indiferencia este suceso; pero los ciegos pordioseros de los alrededores de San Francisco creen que la sonora voz de las recién bautizadas (que no será como los niños de teta) distraerán a los paseantes en perjuicio de sus saquillos: mientras tanto es preciso que el culto divino tenga la mayor pompa imaginable; y yo aseguro a usted que una misma cantidad sin sonoros repiques de campanas es más triste que entierro rezado y mal pagado». Di Stefano, 2010: 186-187. 
tró allí mucho más central y explícita. Alberdi pretendía dar entidad, a través de su texto, a un proyecto que transformara no solo la comprensión y la práctica del derecho, sino también la propia sociedad nacional; y contaba aún para ello con la posibilidad de constituir, junto a sus compañeros generacionales, una elite intelectual dentro del rosismo que guiara al régimen en lo que él consideraba la dirección de, al mismo tiempo, el progreso y la estabilidad política.

Como se ha señalado numerosas veces, el proyecto de Alberdi apuntaba a sustentar su apuesta transformadora a la vez en las características del elemento local, nacional, y una suerte de razón universal cuya forma más acabada podría encontrarse en los más "avanzados" centros intelectuales europeos. Siguiendo el modelo del historicismo romántico, Alberdi no contemplaba ya un progreso trascendente al desarrollo histórico de las naciones, sino uno que le era inmanente, que se encontraba inextricablemente inscripto en este. Resta por responder la pregunta sobre cuáles serían los agentes que, adecuándose a esa fórmula según la cual la razón se volvía inmanente - aunque, en su multiplicidad, nunca dejara de ser una-permitirían llevar adelante esa promesa de desarrollo grabada en la historia de las naciones. En opinión de Alberdi estos debían ser la filosofía y la religión, en alianza y armonía entre ellas.

El Fragmento denota una suerte de "división del trabajo" entre ambas fuerzas: la filosofía aportaría el principio activo, las ideas que permitirían "civilizar" las costumbres, la sociabilidad, el derecho, incluso la religión misma; la religión proporcionaría, en cambio, una especie de sustrato necesario que, asegurando la unión de los ciudadanos por medio de una fe común a la vez que el respeto a las leyes, impediría que la acción de la filosofía se torne estéril e ineficaz. Según Alberdi, «La razón y la fé sostienen el edificio humano: y la ignorancia y la inmoralidad del pueblo es la vida, es el tesoro, de la tiranía: el cristianismo y la filosofía son pues los manantiales de nuestra libertad ${ }^{38}$. Y luego, refiriendo a Lerminier, afirmaba que sin esta alianza la ley es imposible, porque «nace del axioma y del dogma, y tiene su asiento en medio de ellos, y se sostiene en medio de ellos, como ellos por la ley» ${ }^{39}$. Indicaba luego cuál es el papel que cumplía cada uno de ellos en esta ecua-

38 Alberdi, 1886: 176.

39 Idem. Alberdi interpretaba aquí a Lerminier de un modo que se alejaba del sentido expuesto en su Introduction génerále á l'histoire du droit. Para el publicista francés el derecho positivo se componía del elemento filosófico y del elemento histórico, expresados "fórmulas, axiomas y dogmas". Pero no consideraba que dichos dogmas debían tener necesariamente una forma religiosa. Lerminier, 1835: 24. 
ción: «Sin religión no hay ley, porque no hay autoridad en las prescripciones desnudas de todo dogmatismo, pues que el dogma afecta todo el sistema de las facultades humanas. Sin la filosofía no hay ley, pues que la razón es otra guía que el hombre no abandona» ${ }^{40}$.

Alberdi pretendía insertar su trabajo en la línea sintética del eclecticismo francés, que contemplaba al hombre tanto en su faceta "material" como en su faceta "espiritual" - y que, de hecho, hacía del elemento espiritual-moral su característica más destacada-. Es en esta línea que, como señala Jorge Myers, el tópico espiritualista «fue repetido ad nauseam por Echeverría, por Alberdi, por Gutiérrez, etc., en casi los mismos términos utilizados por sus modelos europeos» ${ }^{41}$.

Myers también sostiene, por otro lado, que la transposición cultural de estas nociones fue muy diferente en el territorio rioplatense con respecto a la función que había tenido en Francia y otros países europeos. No solo, afirma este autor, los románticos argentinos no recusaban la revolución — «como sí lo hacían sus arquetipos europeos»-, sino que tampoco se oponían al sensualismo dieciochesco por su oposición explícita a una visión teocéntrica del mundo ${ }^{42}$. Este juicio, puede argumentarse, debe ser matizado. No solo porque los "maestros" europeos de la Joven Generación no recusaran in toto a la Revolución —más allá de los tradicionalistas como Bonald, De Maistre o el primer Lamennais - , aunque sí se opusieran, al menos en un primer momento, a una soberanía popular irrestricta ${ }^{43}$. Más importante aún, los integrantes

40 Idem. Alberdi presenta luego una visión incluso más cruda sobre la importancia de la religión, en la que se expresa su papel como garante del orden social. Y caer en el sensualismo, en este sentido, era para él uno de los mayores peligros en que puede hundirse una sociedad: «Entibiando el dogma de la espiritualidad del alma, el sensualismo priva al hombre de la idea consoladora de una vida futura: se resfría y aniquila toda creencia religiosa, y la sociedad humana pierde su más poderosa garantía. Viene á mirarse el testimonio interno, el éco de la conciencia, como un error supersticioso, como un resto despreciable de los innatistas, y la moral secreta queda sin juez. No solo pues el sensualismo, es un sistema incompleto y falso, sinó también peligroso, considerado meramente en su influjo social y político». Ibidem: 240.

41 Myers, 1998: 423.

42 Idem.

43 Puede pensarse, por ejemplo, en los liberales doctrinarios franceses, y en Guizot en particular. Como señala Pierre Rosanvallon, Guizot no pretendía recusar de plano la Revolución, sino "cerrarla". Esto involucraría una pretendida fusión de principios —monárquico, aristocrático, democrático- que pretendería llevar adelante a través de su peculiar sistema capacitario. También los románticos argentinos pretenderían fusionar principios para finalizar la revolución, aunque no serían los mismos. En el caso local, estos se verían representados por el federalismo - en cuanto elemento popular y autóctono- y el unitarismo - considerado como una razón sin asidero- - El modelo capacitario, de hecho, sería tomado por la Joven Generación para cimentar la unión de dichos elementos. Ver Rosanvallon, 2015. 
de la Nueva Generación no apelaron exclusivamente a un vago espiritualismo, sino que pusieron a la religión en el centro de la escena. Y, a pesar de que por momentos se confundiera con la búsqueda de un "dogma social" puramente humanitario, en términos ampliamente generales sustentarían el conjunto de sus ideas en la creencia en un Dios trascendente, cuyas leyes eran las leyes del progreso general de la humanidad. No era este un Dios ajeno y desconocido, según el modelo deísta, sino el Dios del cristianismo, de cuya palabra los evangelios eran un vehículo privilegiado.

Alberdi consideraba, siguiendo a Leroux, que la filosofía se había elevado hasta llegar a la siguiente fórmula: «el progreso continuo es la ley de la vida del universo». Sin embargo, aunque este progreso continuo parecía ser inmanente a la humanidad o al propio universo, Alberdi introdujo en él la idea de una divinidad como su sostenedora:

Porque todo es imperfecto, todo inacabado bajo el sol, y quiere perfeccionarse eternamente, hasta que la voluntad divina sea por fin satisfecha [...] Entre tanto, nada hay erróneo, ni malo, sinó lo que estorba el desarrollo progresivo de los designios de Dios, que son: porque nada esté quieto en el universo, pues que la obra esté inacabada y quiere proseguir interminablemente ${ }^{44}$.

La providencia divina aparecía, en último término, como garante de esa ley de perfectibilidad indefinida que, según Alberdi, la filosofía había logrado encontrar. No se alejaba, en este sentido, de autores como Jouffroy, Lamennais y Leroux quienes, con diferentes inflexiones, también contemplaban la centralidad de un Dios en que apoyaban sus doctrinas sobre el hombre y la humanidad ${ }^{45}$. Esto sería aún más claro en la tesis presentada por Manuel Quiroga Rosas en 1837, el mismo año de la publicación del Fragmento preliminar, y poco después

44 Alberdi, 1886: 229.

45 En el Cours de droi naturel, por ejemplo, Jouffroy sostenía que «Sin embargo esta idea del orden en sí mismo, más allá de lo alta que sea, no es el último término del pensamiento humano. Este realiza un paso adicional y se eleva hacia Dios que ha creado este orden universal, y que otorga a cada criatura que contribuye a él su constitución, y por consecuencia su fin y su bien» [traducción propia]. Jouffroy, 1834: 50. Más allá de sus muchas diferencias con dicho autor, Leroux también otorgaba a la idea de Dios un papel central en la construcción del orden natural y humano. En su artículo "Aux politiques", publicado en la Revue Encyclopédique en 1832, escribía que: "Ya le he dicho que la soberanía de cada uno toma su fuente del espíritu humano, de la razón humana, y que la razón humana tenía ella misma su fuente en Dios, suprema razón, suprema verdad, ciencia suprema» [traducción propia]. Leroux, 1978: 154. Es difícil saber qué textos específicos de Leroux los jóvenes románticos puedan haber leído, pero estas nociones se repiten en todos sus trabajos de este período. Las referencias a la centralidad de Dios en las obras de Lamennais que llegaron a Buenos Aires, por otro lado, son extremadamente abundantes. Ver Lamennais 1817 y 1834. 
editada en forma de libro. En su primer capítulo, titulado "El derecho en la naturaleza divina", Quiroga Rosas sostenía que:

En el universo no vemos mas que una creacion, un efecto; luego hay una causa creatriz, una causa absoluta, un Dios. Nadie duda que la causa creatriz debe estar en relacion con su criatura: luego Dios está en relacion con el universo ${ }^{46}$.

Las referencias de este autor a la necesaria existencia de una ley divina atravesarían, de hecho, la mayor parte de su disertación. Sin Dios —o, más específicamente, sin la ley de Dios - pensar el derecho, pensar la sociedad misma carecía de sentido. Sin embargo, en la extensa conclusión de su obra, Quiroga Rosas abandonaba muy sugestivamente la apelación al orden divino y entronizaba en cambio a la filosofía como medio para alcanzar la perfección del orden social —idea que, explicaba, había podido inferir de la doctrina de Saint-Simon ${ }^{47}$-.

Retornando al Fragmento preliminar, puede considerarse que también allí el plano religioso retrocede ante la primacía de la filosofía, que se muestra por momentos indiscutible. Si bien para Alberdi la ley del progreso se sostiene sobre la providencia divina, esta, que es absoluta, «no se revela al espíritu humano, sinó traducido por lo relativo» ${ }^{48}$. Y agrega «Dios, como la verdad, no se deja ver en su unidad absoluta, sinó de una vigorosa inteligencia». A partir de ello afirma que

como lo absoluto se revela á la humanidad de mas en mas, de ahí es que el relativo que le espresa quiere ser agrandado en la misma proporción. De aquí la necesidad de una movilidad indefinida en las formas religiosas, so pena de arrojar en desprecio estas formas, por su falta de armonía con las nuevas ideas de la divinidad que ha concebido ulteriormente, la inteligencia siempre progresiva y creciente del género humano ${ }^{49}$.

46 Quiroga Rosas, 1837: 10.

47 Ibidem: 10. En la mirada de Quiroga Rosas una religión revelada se tornaba casi superflua, frente a las capacidades ilimitadas de una razón humana que podía descubrir las propias leyes de Dios. El cristianismo y la "doctrina de Jesús" solo aparecen en su obra, en una nota al pie, como garantes de ciertas garantías terrenas: la libertad individual, contra el panteísmo platónico, y la igualdad de todos los hombres. Ibidem: 47.

48 Alberdi, 1886: 250. En este punto Alberdi seguía de cerca a Leroux, según quien «Dios, la divina luz, Dios que es la Ciencia y la Verdad, se comunica a la Humanidad por medida y gradualmente, y es por los hombres que esta comunicación se hace. Hay entonces en la Humanidad una revelación continua, y los iniciadores se suceden» [traducción propia] Leroux, 1978: 104.

49 Idem. 
Alberdi compartía con autores como Jouffroy y Leroux la noción de que la religión estaba también atravesada por la ley del progreso, y que por lo tanto llevaba en sí una simiente de perfeccionamiento continuo. Sin embargo, no llegaría nunca a poner en duda la sacralidad y perennidad del cristianismo, como sí lo habían hecho dichos autores: Jouffroy había alguna vez vaticinado el reemplazo del cristianismo por el reinado de la filosofía — más allá de que en escritos posteriores hubiera matizado dicha tesis inicial -50 y Leroux imaginaba el derrocamiento de este por una nueva síntesis religiosa que guiaría a la humanidad en el nuevo siglo que despuntaba ${ }^{51}$. Alberdi, evitando las posiciones más radicales, extraería elementos de distintos autores para desarrollar una elaboración propia sobre los alcances de la religión y sobre el alcance y el significado del cristianismo en la sociedad en que vivía.

50 En sus escritos y lecciones producidos durante la década de 1820 y comienzos de 1830 Jouffroy había sostenido que los tiempos del cristianismo habían llegado a su fin, y que sería en un futuro reemplazado por un nuevo tipo de creencia general cuya base sería filosófica. En su artículo "Comment les dogmes finissent", publicado por Le Globe en 1823, se había explayado extensamente sobre el nacimiento, el desarrollo y el final de las creencias colectivas. Si bien en ningún momento del texto mencionó al cristianismo, tácitamente sugería que dicha religión no se adaptaba ya a las necesidades de su propio tiempo. Esto devendría explícito en su curso de filosofía brindado en 1830 en la École normale, editado luego en sus Mélanges philosophiques. Tras exponer por qué motivos consideraba improbable que una nueva religión ocupara en Francia el espacio perdido por el cristianismo, sostendría que sería para él un nuevo tipo de sistema filosófico, sustentado sobre el pensamiento racional, el que debía tomar las riendas de las creencias colectivas. Tanto su propia tarea como la de sus estudiantes debía ser, así, la confección de este nuevo sistema. Ver Jouffroy, 1833: 3-29 y 486-491.

En su Cours de droit naturel, publicado unos años más tarde, su postura sobre este tema sería sin embargo menos radical. Sostenía allí que: «el fondo del cristianismo es demasiado verdadero para que esta gran religión desaparezca, como lo ha hecho el paganismo; su destrucción es un sueño del siglo XVIII, que no se realizará nunca; pero nadie duda que deba sufrir una depuración, y recibir una forma nueva y adiciones notables: de otro modo, la revuelta que ha excitado, la incredulidad presente, y este largo trabajo de la humanidad cristiana, que data del siglo $15^{\circ}$, no tendría sentido, lo que es imposible» [traducción propia]. Jouffroy, 1834: 302-303.

Alberdi, que pudo acceder tanto al Cours como a las Mélanges de Jouffroy, se decantaría en su Fragmento por esta forma más mesurada de abordar la situación del cristianismo.

51 Leroux afirmaba en un artículo de 1832, publicado en la Revue Encyclopédique, que, si bien podía valorar el papel histórico jugado por el cristianismo —en cuanto «la última forma en la que nuestro Occidente ha vivido espiritualmente, moralmente, socialmente»-, dicha religión no constituía la nueva síntesis capaz de guiar a la humanidad en los tiempos por venir: «negamos entonces que el cristianismo tenga la potencia de renacer; y, en este sentido, negamos el cristianismo como negamos las teorías científicas generales del pasado». Consideraba, en cambio, que la nueva religión estaría sostenida por la "razón colectiva", derivada de la "razón suprema", que se manifestaba en cada sujeto y por lo tanto servía como lazo de unión entre ellos. Leroux, 1978: 95 y 155. 
Como se ha visto, Alberdi veía en la providencia divina un fundamento trascendente que garantizaba la ley del progreso indefinido y en la religión una fuerza que sacralizaba las verdades de la filosofía y garantizaba el orden social. Hasta aquí su planteo parece tener un carácter estrictamente deísta, en el que una religión revelada no encuentra lugar. Alberdi llegaría a afirmar, de hecho, que

Cuando de este modo, de la idea del órden absoluto, nuestra razón se ha remontado á la concepción de un ser ordenador, el órden ofrece entonces una nueva faz religiosa, que dobla su virtud obligatoria, pero que no viene á producirla, pues que el órden no tenía necesidad de un carácter religioso para parecernos obligatorio, que por sí solo lo es bastante ${ }^{52}$.

Si una religión revelada no era necesaria para conocer el "orden absoluto", y ni siquiera era imprescindible para sacralizarlo ante los ojos de los hombres, ¿cuál podía llegar a ser su función? Y en este plano la ruptura de Alberdi, tanto con el catolicismo tradicional como con su variante neo-borbónica, era tajante. A su modo de ver, «En cuanto al cristianismo, tan lejos de ser contrario a los intereses filosóficos del mundo, dependerá la felicidad futura de la sociedad humana, de la completa realización política del principio espiritualista, anunciado por Jesu-Cristo: la igualdad» ${ }^{53}$. Y desglosaba luego dicha idea con más detalle, entretejiéndola - en un conjunto de notas al pie-con citas de las Palabras de un creyente de Lamennais:

El cristianismo es la democracia: y su influencia política es el bálsamo que alimenta el desarrollo de la libertad humana. El cristianismo es la libertad. Ser impío es ser esclavo; como ser amo es ser impío. El génio del Evangelio es la igualdad, cuya realización es la libertad. Oprimir y dejar oprimir la libertad, es escupir el Evangelio, es la más espantosa impiedad ${ }^{54}$.

En la mirada de Alberdi, que seguía al Lamennais ya apartado de Roma, el cristianismo se convertía en una promesa de redención estrictamente terrenal, con el mensaje de Jesucristo prometiendo un futuro de democracia y libertad. Como Lamennais y Leroux ${ }^{55}$, parecía encontrar en el pueblo al verdadero representante de la divinidad: «Así el pueblo es el sólo órgano legítimo

\footnotetext{
52 Alberdi, 1886: 156. Aquí Alberdi seguía casi textualmente el Cours de droit naturel de Jouffroy. Jouffroy, 1834: 50.

53 Ibidem: 177.

54 Idem.

55 Citando a Jean Reynaud, Leroux había escrito en su "Aux politiques" que «todo el destino del futuro» podía resumirse en el pensamiento: «La voz del pueblo es la voz de Dios». Leroux, 1978: 104.
} 
de las voluntades y los designios de Dios: de modo que la razón y la voluntad del pueblo son la razón y la voluntad de Dios» ${ }^{56}$. Alberdi, sin embargo, no llevó este argumento hasta sus últimas consecuencias, como sí lo había hecho el ex-abate, y agregó una condición fundamental: «Pero para que esto sea, es menester que el público, es decir, la mayoría, sea racional; porque solo es divina, y por tanto, legislatriz la razón del pueblo, cuando el pueblo, y no una corta minoría que no es pueblo, es racional $\rangle^{57}$. Ese atisbo de radicalismo democrático que emergía en la escritura de Alberdi se mostraba rápidamente abortado, en un escenario donde la voluntad efectiva del pueblo había dado forma al "caudillismo bárbaro" y al rosismo muy particularmente. Afirmaba entonces, podría argumentarse, que el pueblo era santo - con Lamennaispero que sin embargo solo era santo en cuanto fuera capaz de acceder a la razón universal - con Guizot - ${ }^{58}$. El resultado final fue el corrimiento a un segundo plano de ese pueblo al que se invocaba con tanta grandilocuencia y, nuevamente, la re-legitimación de Alberdi y sus compañeros como los depositarios verdaderos de esa razón universal.

El temor al despotismo fue también probablemente el motivo de que Alberdi recusara en forma explícita la perspectiva de los sansimonianos, tendiente a instaurar un poder a la vez material y espiritual ${ }^{59}$, favoreciendo en cambio una postura de tinte "liberal" con respecto al vínculo que debía mediar entre la Iglesia y el Estado. A su modo de ver, «la sanción de la infracción del precepto religioso compete solo al dominio de la conciencia individual ${ }^{60}$ y el Estado por lo tanto no puede involucrarse en dicho proceso. Según Alberdi,

56 Ibidem: 191.

57 Ibidem: 141.

58 Fue Félix Frías quien, a fines de la década de 1830, se apegó con mayor fuerza a los postulados de Lamennais. A su modo de ver, el pueblo constituía una encarnación de la voz de Dios, por lo que una instancia externa a él que lo "educara" casi perdía el sentido. La posición de Frías fue, podría decirse, particularmente inmanentista; dado que el pueblo encarnaba los valores del cristianismo, debía liberárselo para que llegue por sí mismo al futuro de libertad y democracia que este prometía. Para una perspectiva más amplia sobre este personaje puede consultarse Castelfranco, 2018.

59 De acuerdo con Alberdi, los sansimonianos pretendían disolver la separación entre el poder espiritual y el temporal en un nuevo tipo de "poder religioso". A su modo de ver, esto los había conducido «á los resultados más contrarios á la constitución actual de la sociedad humana, y á los fundamentos mismos del cristianismo») Alberdi, 1886: 175. Resulta difícil saber exactamente qué lecturas sansimonianas llegaron a manos de Alberdi. Sin embargo, como sugiere José Oría, es posible que hubiera tenido contacto con las ediciones de Le Globe durante el período en que se apegó a dicha perspectiva. Ver Oría, 1938: 49-50 y Tarcus, 2016: 159.

60 Alberdi, 1886: 174. 
La religión habría perecido si no se espiritualiza y se constituye por sí propia. Jesu-Cristo llenó esta exigencia, despojándola de toda sanción política y temporal, y sujetándola á la sola sanción positiva de una vida futura. De esta manera Dios mismo separó la religión y la política. Ha costado mucha sangre la realización de este divino deslinde, que aun no está acabado ni en la vida de los pueblos, ni en la ciencia. Y sin embargo, mientras no se practique de uno y otro modo, no irán bien los intereses del Estado, ni los de la Iglesia. La dificultad desaparecerá desde que se comprenda que distinguirlos no es dividirlos: lo primero no es necesario, lo segundo es imposible; persuádase de aquello el Estado, y la Iglesia de esto, y lo hará el Estado sin que la Iglesia lo estorbe ${ }^{61}$.

Es posible que Alberdi, al señalar como necesaria la "distinción" entre la Iglesia y el Estado, pensara en la cooptación del clero católico bonaerense llevada adelante por Rosas. Y, si bien no hizo ninguna referencia a la relación del catolicismo con el orden público, sí ilustró, apelando al caso de España, cuáles eran las posibles consecuencias de un catolicismo "fanático" unido con el Estado. España, consideraba, había desarrollado un horror al pensamiento como consecuencia de sus guerras con el islam, primero, y con el luteranismo más adelante. Así, «España no hizo más que ocuparse de las creencias que amenazaban su fe católica» ${ }^{62}$. Como consecuencia de su obstinación "terca y ciega" se había tornado fanática y supersticiosa, pero no había logrado ser religiosa. Alberdi detalló luego algunas de las consecuencias más perniciosas de dicha actitud:

San Ignacio erige una cruzada espiritual contra las ideas progresivas y nuevas de la Europa reformada. La institución de S. Domingo declara á la España en estado perpétuo de sitio contra los heresiarcas Bacon, Leibnitz, Locke, Newton, Grocio, Kepler, y su discípulo francés, el siglo XVIII: prefiere primero verla ignorante toda su vida, sin saber política, legislación, historia, filosofía antes que dejarla pensar á riesgo de hacerse incrédula ${ }^{63}$.

Esto era particularmente problemático porque, advertía Alberdi, quienes habitaban la Confederación Argentina eran a fin de cuentas herederos de esa España "supersticiosa" y "fanática". Lamennais y Leroux consideraban que era necesario dar vida a una religión que pudiera guiar los destinos humanos y que, en cuanto dogma de la humanidad, no debía estar separado de ella misma. Esto era resultado de que, a su modo de ver, el siglo XVIII había destruido y anarquizado las creencias de los hombres y se mostraba perentorio alcanzar una nueva síntesis de unidad. Dicha búsqueda de un nuevo dog-

\footnotetext{
61 Ibidem: 175-176.

62 Ibidem: 249.

63 Idem.
} 
ma colectivo, si bien contemplaba la necesidad de salvaguardar las libertades del individuo - entre ellas la libertad de conciencia - relegaba en ocasiones dicha cuestión a un segundo plano frente a la necesidad de solidificar la anhelada creencia común ${ }^{64}$.

Alberdi consideraba lo mismo, pero con ciertos resguardos explícitos: aunque el egoísmo de los rivadavianos había anarquizado la sociedad y era preciso dar vida a un nuevo dogma que uniera a los habitantes de la nación, remarcó la necesidad de separar la Iglesia del Estado, el poder público de las creencias individuales, en el territorio rioplatense. Dicho énfasis, ausente en los autores antes mencionados, cobraba un carácter apremiante cuando la unión de ambas instituciones parecía ser, en el plano local, un vehículo para la profundización del despotismo ${ }^{65}$.

Quizá por este mismo motivo Alberdi no ensalzara al catolicismo como vehículo de transformación social; estaba demasiado vinculado al régimen de Rosas y al "fanatismo supersticioso" del pasado español. Al mismo tiempo, en un escenario regido por la censura en lo ateniente a la publicación de ideas religiosas, y en el que muy pocos creían posible —o deseable - desarticular el entrelazamiento de la Iglesia con el Estado, probablemente existiera un margen acotado para realizar una crítica más abierta de la Iglesia Católica ${ }^{66}$. Las nociones religiosas presentes en el Fragmento, así, despliegan un entretejido entre aquellas ideas que era posible expresar y las que debían ser calladas, y entre aquellas que - quizá - fuera deseable defender pero que la realidad local tornaba en apariencia insostenibles.

${ }^{64}$ En los escritos de Leroux y Lamennais que circularon en la Buenos Aires de aquellos años la defensa de la libertad de conciencia y de la separación de la Iglesia y del Estado para conseguirla no era particularmente enfatizada. Sobre las tensiones entre la búsqueda de una creencia colectiva y la salvaguardia de los derechos individuales en estos autores puede consultarse Bénichou 2012: 166-169 y 337-340.

65 Su prédica, en este sentido, se acercaba más a la de Jouffroy. Dicho autor, también atravesado por la contradicción entre la búsqueda de una creencia colectiva y la defensa de las libertades individuales, subrayó la necesidad imperiosa de proteger estas últimas. En su Cours de droi naturel escribió que, si emergiera la necesidad ineludible de optar entre ambos términos, «sería la presciencia divina antes que la razón humana la que debería ser sacrificada» [traducción propia]. Jouffroy, 1834: 131. Sobre este tema puede consultarse Bénichou, 2012: 34-38.

66 La única línea que Alberdi dedicó a este tema en el Fragmento — más allá de su denuncia del catolicismo español - señalaría como uno de los errores del siglo XVIII el «haber comprendido el pensamiento puro, la idea primitiva del cristianismo, y el sentimiento religioso, bajo los ataques contra la forma católica» Ibidem: 123. Pero la denuncia de estos "excesos" no conllevaría, sin embargo, una defensa de la fe católica. Alberdi diría del luteranismo, por ejemplo, que no era más que «un primer movimiento de emancipación del pensamiento europeo y moderno», lo que era bastante más con respecto a lo que tenía que decir sobre el catolicismo. Ibidem: 249. 
Si había algunas cuestiones que Alberdi se veía obligado a silenciar, tanto por la censura de prensa como para interpelar a un régimen que hacía de su alianza con la Iglesia Católica una bandera, este ya no sería el caso con la Creencia social redactada por Echeverría un año más tarde. La relación de los jóvenes románticos con el rosismo, en 1838, se había ya tensado fuertemente: el Salón Literario había cerrado sus puertas a comienzos de ese año y el periódico La Moda había sido virtualmente clausurado. Nucleados ahora en la clandestina Asociación de la Joven Generación Argentina, su oposición al rosismo, y en general al statu quo, comenzó a adquirir un cariz más radical.

Como se ha señalado muchas veces, el objetivo de la Creencia social redactada por Echeverría, una suerte de manifiesto de la Joven Argentina, tenía como objeto fundar un nuevo "dogma social" unificador, que permitiera fusionar y dejar atrás las doctrinas unitarias y federales. Se buscaba constituir, así, una tercera fuerza superadora de las anteriores que abrevara directamente del "espíritu de mayo" - caracterizado por la búsqueda de la igualdad y la libertad-, y que encontraría como campo de acción la educación popular y, por medio de ella, la progresiva transformación de la sociabilidad y las costumbres. Mucho menos se ha escrito, sin embargo, sobre el lugar destacado que la religión ocupa en dicho texto ${ }^{67}$.

Echeverría referiría, en su Ojeada retrospectiva de 1846, los debates suscitados en torno a la inclusión o no de motivos religiosos en la Creencia. En sus palabras, «opinaron algunos que nada se hablase de religión, otros invocaron la filosofía» ${ }^{68}$. La religión, sin embargo, que para Echeverría era absolutamente insoslayable, terminaría ocupando un lugar de relativa centralidad en la economía textual de la Creencia. La pregunta que debe responderse, ciertamente, involucra el carácter de esa apelación a la religión.

Puede afirmarse, en primer lugar, que la Creencia de Echeverría posee mucho terreno en común con el Fragmento de Alberdi — este último, a fin de

67 José Ingenieros, en su Evolución de las ideas argentinas, es quien quizá más atención le prestara a esta cuestión. Su hipótesis de que las inflexiones religiosas de la Creencia social son una copia del Nuevo Cristianismo de Saint-Simon, sin embargo, puede ser puesta en cuestión. Más allá de que, de forma similar al último Saint-Simon, Echeverría encontrara en el cristianismo un principio moral terreno, su mayor influencia en esta línea es Lamennais, antes que Saint-Simon. No solo cita al primero directamente, y no hace lo mismo con el segundo, sino que, siguiendo a Lamennais, se ocupa tanto del vínculo del cristianismo con la libertad y con la igualdad. El interés de Saint-Simon por la libertad era ciertamente muy secundario. Por otro lado, también puede verse un tinte claramente liberal en el texto de Echeverría, que lo aleja tanto de uno como del otro autor antes citados. Para las ideas de Ingenieros sobre este tema ver Ingenieros, 1961, vol. 2: 253-310.

68 Echeverría, 1846: XVIII. 
cuentas, colaboró con Echeverría en la escritura del manifiesto generacional—. Sin embargo, en las páginas de la Creencia social las ideas religiosas antes sostenidas por Alberdi sufrieron algunas transformaciones y sus componentes heterodoxos fueron llevados aún más lejos.

La primera diferencia notable de la Creencia social con respecto al Fragmento preliminar o, incluso más claramente, a la tesis de Quiroga Rosas, es que Echeverría coloca un menor énfasis en la existencia de una providencia divina trascendente que garantizara el orden del universo. En su planteo lo divino tiende a confundirse más íntimamente con lo humano y la religión no parece ser otra cosa, en último término, que la sacralización de la propia moral natural de la humanidad. A su modo de ver, de hecho, el cristianismo era la mejor "religión positiva" porque «no es otra cosa que la revelación de los instintos morales de la humanidad» ${ }^{69}$. Y el Evangelio, así, «es la ley de Dios, porque es la ley moral de la conciencia y la razón ${ }^{70}$. Esta tenía, para Echeverría, contornos relativamente definidos: «El Evangelio es la ley del amor, y como dice el Apóstol Santiago, la ley perfecta, que es la ley de la libertad. El cristianismo debe ser la religión de las democracias» ${ }^{71}$.

Por otro lado, Echeverría también consideraba necesaria una alianza entre la religión y la filosofía para llevar adelante la tarea transformadora de la Joven Generación. Y, nuevamente, las tareas de ambas eran claras. La filosofía era definida como «el ojo de la intelijencia examinando é interpretando las leyes necesarias que rigen al mundo físico y moral, ó al universo». Por su parte, «la religión es el cimiento moral sobre que descansa la sociedad, el bálsamo divino del corazón, la fuente pura de nuestras esperanzas venideras, y la escala mística por donde suben al cielo los pensamientos de la tierra» ${ }^{72}$. Y, de modo similar a lo que Alberdi planteara en el Fragmento, parecía ser la filosofía la que en realidad ocupaba el lugar de primacía en este binomio:

La filosofía reconoce á la razon individual como único juez de todo lo que toca al individuo; y á la razon colectiva ó al consensus general como el árbitro soberano de todo lo que toca á la sociedad. [...] La filosofía ilumina la fé, esplica la religion y la subordina también á la lei del progreso. La filosofía en la naturaleza inerte busca la lei á su generacion; en la animalidad, la lei del desarrollo de la vida de todos los séres; en la historia el hilo de la tradicion progre-

69 Echeverría, 1941: 426.

70 Idem.

71 Idem. Al hablar de estos temas Echeverría citaría a Lamennais. Con respecto a la libertad, por ejemplo: «La libertad es el pan que los pueblos deben ganar con el sudor de su rostro» (extraído de las Palabras de un creyente, capítulo XXXVIII). Echeverría, 1941: 428.

72 Ibidem: 434. 
siva de cada pueblo y de la humanidad y por consiguiente la manifestacion de los designios de la providencia ${ }^{73}$.

Llegado a este punto de exaltación de la filosofía por sobre cualquier otra rama del quehacer humano, Echeverría llegó más lejos que nunca en su heterodoxia religiosa, coqueteando con la noción de una "religión racional" como la que, a su entender, perseguía Leroux:

La Filosofía presiente ya y anuncia el nacimiento de una religión racional del porvenir más amplia que el cristianismo, que sirva de base al desenvolvimiento del espíritu humano, y á la reorganización de las sociedades europeas, y que satisfaga plenamente las necesidades actuales de la humanidad. ¿Quién será el revelador de esa religión? La humanidad misma. Esta idea que constituye el principio fundamental de la doctrina de Lerroux y su escuela, no ha salido aún de la esfera de la especulación, y nos reducimos á anunciarla, no siendo tiempo todavía de ventilar nosotros las cuestiones que envuelve. Nuestra fé en el cristianismo es completa: lo adoptamos además como la religión del pueblo, aun cuando quisiéramos verlo reinar con toda su pureza y magestad ${ }^{74}$.

Echeverría, a diferencia de Alberdi, daba un paso en la dirección más radical de la religiosidad humanitaria francesa. Ese paso, sin embargo, quedaría trunco, «no siendo tiempo todavía» de ventilar tales temas en el Río de la Plata. El cristianismo, al que consideraba la religión del pueblo, era la que en sus palabras los jóvenes románticos abrazaban. Probablemente Echeverría no quisiera repetir el error que adjudicaba a los unitarios, de importar doctrinas extrañas al sentir nacional que solo podían ser agentes de agitación interna y anarquía. Sobre todo en un plano tan central como el religioso, sobre el cual debía sostenerse el pregonado proceso de regeneración social. Según Echeverría, este se abriría camino por medio de la educación de las masas; así podrían abrírseles, algún día, las puertas de la soberanía. La religión cumpliría también un papel fundamental sobre esas masas cuya adultez política

73 Idem.

74 Idem. Leroux, tras negar la supervivencia del cristianismo como dogma religioso dominante, explicaba en un artículo de 1832 qué consistía para él la religión por venir: «la soberanía de todos o del pueblo tiene ella misma su fuente en el espíritu humano, y más fundamentalmente aún en Dios, suprema razón, suprema verdad, ciencia suprema. Usted ve entonces que hay algo en común entre cada uno considerado como soberano, y todos considerados como soberanos. Este algo en común es el espíritu humano, es la razón colectiva, derivada de la Razón suprema. Entonces esta razón humana derivada de la Razón suprema, común a cada uno y a todos, puede servir de enlace a cada uno y a todos. La manifestación de este término común a cada uno y a todos es lo que yo llamo religión» [traducción propia]. Leroux, 1978: 154-155. 
futura se auguraba: «moralizándolas, fecundará en su corazón los gérmenes de las buenas costumbres» ${ }^{75}$.

La esfera religiosa, entonces, resultaba fundamental para la transformación de la sociedad. Pero esto no significaba que Echeverría defendiera la unión de la esfera espiritual y de la esfera temporal. A su modo de ver, «Dios es el único juez de los actos de conciencia, y ninguna autoridad terrestre debe usurpar esa prerrogativa divina, ni podrá hacerlo aunque quiera, porque la conciencia es libre» ${ }^{76}$. Y, en una referencia que se acerca al lenguaje lamennesiano de las Palabras de un creyente afirma que «los tiranos han fraguado de la religión cadenas para el hombre, y de aquí ha nacido la impura liga de poder y altar» ${ }^{77}$.

Echeverría probablemente tuviera al rosismo en mente al realizar esos comentarios. Aún en mayor medida que Alberdi observaba la cooptación política del clero católico como un pernicioso refuerzo para lo que contemplaba como un régimen despótico. En El matadero, escrito a fines de la década de 1830, pintaba el cuadro de una Iglesia fanática y supersticiosa subordinada al poder de Rosas. Cuando refiere al diluvio que se abate sobre la ciudad, señala que desde los púlpitos se echa la culpa de dicho "castigo divino" a las acciones de los unitarios. La alianza del Estado con la Iglesia era, para Echeverría, particularmente temible:

Pero no es extraño [que haya estómagos privilegiados y estómagos sujetos a las leyes], supuesto que el diablo con la carne suele meterse en el cuerpo y que la iglesia tiene el poder de conjurarlo: el caso es reducir al hombre a una máquina cuyo móvil principal no sea su voluntad sino la de la iglesia y el gobierno. Quizá llegue el día en qu e sea prohibido respirar aire libre, pasearse y hasta conversar con un amigo, sin permiso de autoridad competente. Así era, poco más o menos, en los felices tiempos de nuestros beatos abuelos que por desgracia vino a turbar la revolución de Mayo $^{78}$.

En la mirada de Echeverría, la unión de la Iglesia con el Estado llevaba en sí el germen del despotismo, como lo atestiguaba el período colonial. Por este mismo motivo afirmaba que «el principio de la libertad de conciencia jamás podrá conciliarse con el dogma de la religión del Estado» ${ }^{79}$. Y, con respecto a los sacerdotes, enfatizó que su misión «es exclusivamente espiritual, porque mezclándose a las pasiones e intereses mundanos, compromete

\footnotetext{
75 Ibidem: 435.

76 Ibidem: 426.

77 Ibidem: 427.

78 Echeverría, 1871: 567-568.

79 Echeverría, 1941: 427.
} 
y mancha la santidad de su ministerio» ${ }^{80}$. Su palabra, siguiendo la de Cristo, deberá ser una de fraternidad y unión: "Amad a vuestro prójimo como a vosotros mismos: amad a vuestros enemigos $\rangle^{81}$. El sacerdote, por lo tanto, debía predicar una moral de carácter estrictamente humano, que cimentara la concordia entre los hombres. Y, si bien no llegara a decirlo en ese momento, posiblemente sospechara que la Iglesia católica, al menos en la forma en que Echeverría podía contemplarla, no sería el agente más adecuado para sobrellevar dicha tarea.

\section{REFLEXIONES FINALES}

Roberto Di Stefano sostiene que, en su faz pública, «por lo general, la cuestión religiosa [en el Río de la Plata] seguirá siendo abordada, hasta la década de 1860, desde posiciones identificadas con el universo de representaciones católico». Aclara, a su vez, que «es dable advertir una progresiva vaguedad en esa identificación, que denota la bifurcación de los senderos que estaban transitando el catolicismo por un lado y sectores nada marginales de la elite cultural y política por el otro» ${ }^{82}$. Tampoco omite que algunos de los integrantes más conspicuos de la Joven Generación combinaron «una genérica adhesión a la fe cristiana» con «críticas más o menos veladas a las prácticas del catolicismo heredado» ${ }^{83}$. Las páginas anteriores ponen de manifiesto la magnitud de esa veta "heterodoxa", que en el caso de Echeverría bordeó incluso - aunque sin materializarse - el abandono de una adscripción cristiana para avanzar hacia una "religión filosófica".

Como se ha visto, el Fragmento Preliminar de Alberdi, la tesis de Quiroga Rosas y numerosos artículos incluidos en El Iniciador manifestaron un alejamiento tácito, aunque no por eso menos perceptible, del marco de referencias católico. Esto no significa, de ningún modo, que consideraran irrelevante a la religión como un pilar del orden social; no escaparon a la lógica de un "primer umbral de laicidad", según lo definiera Jean Baubérot ${ }^{84}$. Pero
80 Idem.
81 Idem.
82 Di Stefano, 2010: 190.
83 Ibidem: 180.
84 Jean Baubérot, analizando el caso francés, propone pensar el proceso de laicización a partir de un conjunto de "umbrales de laicidad", considerados como "tipos ideales", en los cuales las lógicas institucionales y su vínculo con el componente religioso manifiestan dife- rencias. El primer umbral de laicidad, a su modo de ver, tuvo como elementos centrales una fragmentación institucional — por la cual la religión dejó de ser portadora de un sentido que 
la forma específicamente católica del culto estaba demasiado vinculada al rosismo y a los resabios del mundo colonial como para resultarles funcional a la hora de enunciar sus proyectos regenerativos. Ese mismo motivo los condujo a propugnar la separación de la Iglesia y el Estado, aunque no con el objeto de "secularizar" la sociedad, sino de vivificar una fe religiosa que consideraban intrínseca al pueblo.

Como señala Palti, el pensamiento historicista rompió con la concepción ilustrada de un "tiempo" y una "razón" que se preexistían mutuamente, ya plenamente constituidas, en favor de visión según la cual no existía una razón por fuera de la historia, así «ella no era sino una lógica desplegada en el propio encadenamiento objetivo de los acontecimientos $\rangle^{85}$. Algo muy similar ocurría con la esfera religiosa, tan sometida a la ley del progreso como todos los otros elementos de la vida humana: esta se "revelaba" a los sujetos de acuerdo a sus específicas capacidades sociales y costumbres, y se presentaba así como inmanente al desarrollo específico de cada nación. Si el catolicismo había sido la forma religiosa dominante durante el período colonial, no necesariamente tenía que serlo luego de que este se disolviera.

El estar alejados de los cargos públicos, podría argumentarse, permitió a los jóvenes románticos cierta independencia con que los publicistas del período rivadaviano no habían contado. Provistos de la formación laica que habían recibido en las aulas universitarias y de las lecturas "espiritualistas" que llegaban de Francia - a las que recurrieron selectivamente, combinando los fragmentos de distintos autores de acuerdo a sus propios intereses y perspectivas - pudieron pensarse como una elite intelectual que no solo se ocuparía de transformar la fisonomía política del país, sino incluso la religiosa: ambas estaban, para ellos, íntimamente entrelazadas.

Ningún debate emergería sobre estas cuestiones, sin embargo, durante el poco tiempo que medió entre la publicación del Fragmento Preliminar y el exilio generalizado de quienes integraron la Nueva Generación. En ningún momento los textos que vieron la luz en ese período recusaron explícitamente al catolicismo o a la Iglesia, lo que quizá haya favorecido que sus apreciaciones religiosas pasaran en mayor o menor medida inadvertidas. El pronto destierro abortó cualquier apertura a la polémica, y estos temas solo volverían a tratarse en Buenos Aires décadas más tarde y bajo formas muy diferentes.

concerniera a todos los aspectos de la vida - acompañada de una continuada legitimidad social de lo religioso, pensado como fundamento de la moral y garante de la unidad nacional. Baubérot, 2017. Algunos autores han procurado estudiar el proceso de laicización argentino sobre la base de dichos conceptos. Ver Di Stefano, 2011 y Mauro 2014.

85 Palti, 2009: 41. 
Estas ideas seguirían siendo expresadas por los integrantes de la Joven Generación durante los primeros años del exilio, aunque el imperativo de la acción política limitara el espacio otorgado a aquellos trabajos que buscaban plantear una reflexión profunda al respecto. El fracaso de las luchas contra el régimen rosista, por otro lado, depositaría a los jóvenes intelectuales en distintos países de Sudamérica y Europa, donde sus caminos lentamente comenzaron a bifurcarse. La estructura de sentimientos que todos compartían, y que los llevó a buscar en la religión una herramienta de transformación social vinculada a un ideal democrático, comenzaría a cristalizar en opciones de distinto tipo. Vicente Fidel López y Juan María Gutiérrez se acercarían cada vez más, aunque con un diferente nivel de intensidad, al librepensamiento y al anticlericalismo. Echeverría también devendría anticlerical, aunque por una vía distinta: cada vez más adheriría al credo de la religión humanitaria, contemplando en el clero católico un escollo para acceder a la promesa de la fraternidad universal. Alberdi terminaría adoptando un catolicismo moderado, al que consideraría como un elemento importante para el orden social, conjugado con una posición liberal que consideraba esencial la libertad de cultos. Félix Frías y Juan Thompson, por último, comenzarían a ver en la fe católica a virtualmente el único sostén sólido que pudiera garantizar el orden y conjurar la amenaza, siempre acechante, del despotismo y la anarquía.

El proceso de disolución de esa "estructura de sentimiento" estaría acompañado por la búsqueda de encontrar nuevas respuestas al conundrum rosista: ¿cómo seguir sosteniendo una perspectiva historicista, que enfatizara la importancia de las costumbres y las creencias locales, cuando estas parecían conducir, inexorablemente, a la consolidación y perpetuación del régimen de Rosas? El "consenso historicista" comenzaría lentamente a fracturarse. Alberdi, influido por Chevalier, abogaría por el "trasplante" radical de las costumbres europeas en América por medio de la inmigración y el aprendizaje por el trabajo. Sarmiento, en sus viajes por Estados Unidos, delinearía a una suerte de sujeto humano trascendental, capaz de escapar, por medio del trabajo sobre la historia y sobre sí mismo, a los imperativos de su medio ${ }^{86}$. Frías encontraría en el catolicismo una ley moral universal que creía ver consolidarse en la Francia de la década de 1850, y que debía difundirse en América para prepararla para la democracia. A la par que dichos personajes torcieron sus lenguajes políticos hasta finalmente romperlos, debieron recomponer también el lugar que le otorgaban a la religión en sus proyectos para construir una nación argentina.

86 Palti, 2009: 70-75. 


\section{BIBLIOGRAFÍA}

Alberdi, Juan Bautista, Obras completas de Juan Bautista Alberdi, tomo I, Buenos Aires, Imprenta de "La Tribuna Nacional", 1886.

Alberdi, Juan Bautista, "Mi vida privada que se pasa toda en la República Argentina", Autobiografía. La Evolución de su pensamiento, Buenos Aires, Jackson, 1953.

Alcorta, Diego, Lecciones de filosofía, Buenos Aires, Fondo Nacional de las Artes, 2001.

Baubérot, Jean, Histoire de la laïcité en France, París, Presses Universitaires de France / Humensis, 2017.

Bénichou, Paul, El tiempo de los profetas. Doctrinas de la época romántica, Ciudad de México, FCE, 2012.

Betria Nassif, María Mercedes, Penser la politique: la géneration de 1837 et l'institution de l'ordre politique moderne, 1830-1853. Les regards d'Echeverría et d'Alber$d i$, tesis doctoral, Université Paris VIII y Universidad Nacional de Rosario, 2013.

Bruno, Paula, "Un balance acerca del uso de la expresión generación del 80 entre 1920 y 2000", Secuencia. Revista de Historia y Ciencias Sociales, 68 (México D. F., 2007): 115-161. https://doi.org/10.18234/secuencia.v0i68.1007

Buonocuore, Domingo, Libros y bibliófilos durante la época de Rosas, Córdoba, Universidad Nacional de Córdoba, 1969.

Calvo, Nancy, "Lo sagrado y lo profano. Tolerancia religiosa y ciudadanía política en los orígenes de la república rioplatense", Andes. Antropología e historia, 15 (Salta, 2004): 151-181.

Calvo, Nancy, "Voces en pugna. Prensa política y religión en los orígenes de la República Argentina”, Historia Sacra, LX/122 (Madrid, 2008): 575-596. https://doi. org/10.3989/hs.2008.v60.i122.69

Castelfranco, Diego, ¿Dios y libertad? Félix Frías y el surgimiento de una intelectualidad y un laicado católicos en la Argentina del siglo XIX, tesis doctoral inédita, Buenos Aires, Universidad Nacional de General Sarmiento e Instituto de Desarrollo Económico y Social, 2018.

Di Pasquale, Mariano, "La recepción de la Idéologie en la Universidad de Buenos Aires. El caso de Juan Manuel Fernández de Agüero (1821-1827)", Prismas. Revista de Historia Intelectual, 15 (Buenos Aires, 2011): 63-86.

Di Pasquale, Mariano, “Apuntes en torno a la historia intelectual Argentina en el siglo XIX. Metodologías, perspectivas y desafíos”, Historiografías, 4 (Zaragoza, 2012): 27-46. https://doi.org/10.26754/ojs_historiografias/hrht.201242479

Di Pasquale, Mariano, "Un estímulo filosófico en la temprana profesionalización de la medicina en Buenos Aires, 1820-1840", Revista Internacional de Humanidades Médicas, II (Madrid, 2013): 15-29. https://doi.org/10.37467/gka-revmedica.v2.1307 
Di Stefano, Roberto, El púlpito y la plaza: clero, sociedad y politica de la monarquía católica a la república rosista, Buenos Aires, Siglo XXI, 2004

Di Stefano, Roberto, Ovejas Negras. Historia de los anticlericales argentinos. Buenos Aires: Sudamericana, 2010.

Di Stefano, Roberto, "Por una historia de la secularización y de la laicidad en la Argentina", Quinto Sol, XV / 1 (Santa Rosa, 2011).

Echeverría, Esteban, "Código o declaración de los principios que constituyen la creencia social de la República Argentina”, en Academia Nacional de la Historia, El Iniciador. Reproducción facsimilar, Buenos Aires, Guillermo Kraft Ltda., 1941 [1839].

Echeverría, Esteban, Dogma Socialista de la Asociación de Mayo, precedido de una ojeada retrospectiva sobre el movimiento intelectual en el Plata desde el año 37, Montevideo, Imprenta del Nacional, 1846.

Echeverría, Esteban, “El Matadero”, Revista del Río de la Plata. Periódico mensual de historia y literatura de América, I (Buenos Aires, 1871): 563-585.

Falcón, Ricardo, "La visión de España en la Generación del 37”, en X Jornadas Interescuelas / Departamentos de Historia, Santa Fe, 2005.

González Bernaldo, Pilar, "Sociabilidad y opinión pública en Buenos Aires (18211852)", Historia Contemporánea, 27 (Leioa, 2003): 663-694.

Gónzalez Bernaldo, Pilar, Civilidad y política en los orígenes de la nación argentina. Las sociabilidades en Buenos Aires, 1829-1862, Buenos Aires, FCE, 2008.

Halperin Donghi, Tulio, "Intelectuales, sociedad y vida pública en Hispanoamérica a través de la literatura autobiográfica", El espejo de la historia. Problemas argentinos y perspectivas latinoamericanas, Buenos Aires, Sudamericana, 1987.

Ingenieros, José, La evolución de las ideas argentinas, v. 2, Buenos Aires, Editorial Futuro, 1961.

Jouffroy, Théodore, Mélanges philosophiques, París, Paulin Libraire-Éditeur, 1833.

Jouffroy, Théodore, Cours de droit natural, París, Prévost-Crocius Éditeur, 1834.

Lamennais, Felicité Robert de, Essai sur l'indifférence en matière de religion, París, Imprimerie de Leblanc, 1817.

Lamennais, Felicité Robert de, Paroles d'un croyant, París, Eugène Renduel, 1834.

Lamennais, Felicité Robert de, El dogma de los hombres libres. Palabras de un creyente [traducción y prólogo de Mariano José de Larra], Madrid, Imprenta de Don José María de Repullés, 1836.

Lempérière, Annick, "Los hombres de letras hispanoamericanos y el proceso de secularización (1800-1850)", Carlos Altamirano (dir.), Historia de los intelectuales 
en América Latina, I, La ciudad letrada, de la conquista al modernismo, Buenos Aires, Katz, 2008: 242-268.

Lerminier, Eugène, Lettres philosophiques adressées á un berlinois, París, Paulin Libraire-Éditeur, 1833.

Leroux, Pierre, Oeuvres 1825-1850), Ginebra, Slatkine Reprints, 1978.

López, Vicente Fidel, “Autobiografía”, La Biblioteca I / 1 (Buenos Aires, 1896): 325-355.

Mauro, Diego, "Procesos de laicización en Santa Fe (Argentina): 1860-1900. Consideraciones sobre la "Argentina liberal y laica", Revista de Indias LXXIV/261 (Madrid, 2014): 539-560.

Martínez, Ignacio, Una nación para la Iglesia argentina. Construcción del Estado y jurisdicciones eclesiásticas en el siglo XIX, Buenos Aires, Academia Nacional de la Historia, 2013.

Myers, Jorge, Orden y virtud. El discurso republicano en el régimen rosista, Buenos Aires, Universidad Nacional de Quilmes, 1995

Myers, Jorge, "La Revolución en las Ideas: La Generación Romántica de 1837 en la Cultura y en la Política Argentinas", Noemí Goldman (ed.), Nueva Historia Argentina, tomo III, Buenos Aires, Sudamericana, 1998.

Myers, Jorge, "El letrado patriota: los hombres de letras hispanoamericanos en la encrucijada del colapso del imperio español en América", Carlos Altamirano (dir.), Historia de los intelectuales en América Latina, I, La ciudad letrada, de la conquista al modernismo, Buenos Aires, Katz, 2008: 381-417.

Oría, José A., "Prólogo", La Moda. Gacetín semanal de música, de poesía, de literatura, de costumbres, 1837-1838, Buenos Aires, Academia Nacional de la Historia, 1938.

Palti, Elías, El momento romántico: nación, historia y lenguajes políticos en la Argentina del siglo XIX, Buenos Aires, Eudeba, 2009.

Pocock, J. G. A., "The reconstruction of discourse: towards the historiography of political thought, en, Political thought and history. Essays on Theory and Method, Cambridge, Cambridge University Press, 2009.

Quiroga Rosas, Manuel, Tesis sobre la naturaleza filosófica del derecho, Buenos Aires, Imprenta de la Libertad, 1837.

Rodríguez Martín, Bárbara, Juan María Gutiérrez y su contribución periodística (1833-1852) a la crítica cultural hispanoamericana, Tesis doctoral, Universidad de la Laguna, 2005. http://riull.ull.es/xmlui/handle/915/9855

Rosanvallon, Pierre, El momento Guizot. El liberalismo doctrinario entre la Restauración y la Revolución de 1848, Buenos Aires, Biblos, 2015. 
Tarcus, Horacio, El socialismo romántico en el Río de la Plata (1837-1852), Buenos Aires, FCE, 2016.

Weinberg, Félix, El Salón Literario de 1837, Buenos Aires, Librería Hachette, 1977.

Williams, Raymond, Marxismo y literatura, Buenos Aires, Las Cuarenta, 2009.

Fecha de recepción: 5 de abril de 2018.

Fecha de envío de las modificaciones: 11 de junio de 2018.

Fecha de aceptación: 24 de agosto de 2018.

\section{Towards a new Christianity? \\ Religion and heterodoxy in the Joven Generación Argentina}

This paper analyses the religious perspectives of the Joven Generación Argentina in the late 1830s. Its members thought of religion, and more specifically of Christianity, as a strictly earthly vector of regeneration to support, alongside philosophy, their project of social and political reform. They also manifested a veiled hostility towards Catholicism, which they associated with the set of colonial customs they intended to abandon, with a Spain they considered "retrograde" and with the "tyranny" of Juan Manuel de Rosas. Their religious perspectives did not constitute a systematic approach, however; they did give shape to a "structure of feelings".

KeY words: Joven Generación Argentina; 19th century; Christianism; Juan Bautista Alberdi; Esteban Echeverría. 